Polish Journal of Microbiology

2016, Vol. 65, No 2, 191-200

ORIGINAL PAPER

\title{
Levels of Organic Compounds, Number of Microorganisms and Cadmium Accumulation in Festuca ovina Hydroponic Culture
}

\author{
MAŁGORZATA MAJEWSKA* and ANNA SŁOMKA \\ Department of Environmental Microbiology, Institute of Microbiology and Biotechnology, \\ Maria Curie-Skłodowska University, Lublin, Poland
}

Submitted 14 July 2015, revised 12 October 2015, accepted 18 October 2015

\begin{abstract}
Understanding the microbiological, biochemical and physiological aspects of phytoremediation of soil and water environments polluted to different degrees with heavy metals has very important theoretical and practical implications. In this study, a comparison was made between total cadmium concentration in root and shoot tissues as well as concentrations of particular fractions of Cd immobilized by roots of Festuca ovina (Sheep's fescue) hydroponically cultivated in nutrient solutions supplemented with $1 \mu \mathrm{g} \mathrm{Cd} \mathrm{ml} l^{-1}$ and those cultivated at $10 \mu \mathrm{g} \mathrm{Cd} \mathrm{ml}{ }^{-1}$. After three weeks of $F$. ovina cultivation, the number of bacterial CFU and the amounts of organic chelators, siderophores, proteins and reducing sugars in the growth medium and on the root surface were higher at 10 than at $1 \mu \mathrm{g} \mathrm{Cd} \mathrm{ml}^{-1}$. The grass also reacted to the high $\mathrm{Cd}$ concentration by a decrease in plant growth and dehydrogenase activity in root tissues. The concentration of $\mathrm{Cd}$ determined in fractions bound with different strength in roots was significantly dependent on Cd concentration in the growth medium. When the plants were grown at $1 \mu \mathrm{g} \mathrm{Cd} \mathrm{ml}{ }^{-1}, 9 \%$ of the immobilized cadmium was loosely bound to the root surface, $20 \%$ was exchangeable adsorbed, and $28 \%$ was bound by chelation; at $10 \mu \mathrm{g} \mathrm{Cd} \mathrm{ml} l^{-1}$, the respective values were $12 \%, 25 \%$, and $20 \%$. About $43 \%$ of the immobilized cadmium remained in roots after sequential extraction, and bioaccumulation factors in shoots had the same values independently of Cd concentration. At both $\mathrm{Cd}$ concentrations, the cadmium translocation index for F. ovina was low $(<1)$, which is why this grass can be recommended for phytostabilization of the metal under study.
\end{abstract}

Ke y word s: hydroponic culture under different Cd concentrations, metal chelators, phytoremediation, sequential extraction of Cd

\section{Introduction}

Cadmium is not essential for plant, animal and human metabolism (Van der Perk, 2006). The only known biological function of $\mathrm{Cd}$ has been described in marine diatoms under zinc limitation. In those conditions, a low concentration of Cd acted as a cofactor in Cd-carbonic anhydrase (Xu and Morel, 2013). Cadmium tends to be less strongly adsorbed than other divalent metals and, therefore, it is more labile in soil and more available to plants (An et al., 2011; Kacálková et al., 2014). Areas located in industrial regions can contain high concentrations of heavy metals (HM). For example, in southern Poland, there are regions with HM-polluted sites (e.g. Bolesław near Olkusz, Upper Silesia) where the concentrations of $\mathrm{Zn}, \mathrm{Pb}$ and $\mathrm{Cd}$ exceed 40,000 $\mathrm{mg} \mathrm{kg}^{-1}, 5,000 \mathrm{mg} \mathrm{kg}{ }^{-1}$ and $300 \mathrm{mg} \mathrm{kg}^{-1}$, respectively (Majewska et al., 2011). In such cases, it is very important to prevent the migration of these metals to surrounding uncontaminated soils. Apart from physico-chemical stabilization (compost applica- tion, liming etc.), phytostabilization can be taken into account as a method of remediation of HM-contaminated soils (Alvarenga et al., 2008). This method is an aesthetically pleasing strategy that uses the ability of metal-tolerant plants to grow in and cover contaminated ground. Phytostabilization consists in sequestration of metals within roots and the rhizosphere without translocating them into the above-ground plant tissues (Mendez and Maier, 2008; Ganesan, 2012; Zhang et al., 2012). Plants are colonized by endophytic and rhizospheric microorganisms which increase the resistance of their hosts to environmental stresses (Jha et al., 2013). These microorganisms can play an important role in phytoremediation of soils polluted with heavy metals (Soleimani et al., 2010) and many other, especially organic, contaminants (Gerhardt et al., 2009).

Organic components of root exudates are a good source of nutrients and energy for microorganisms, hence, a microbial community living in the rhizosphere can be 10-100 times larger than the same type of community found in bulk soil (Huang and Germina, 2002).

\footnotetext{
* Corresponding author: M. Majewska, Department of Environmental Microbiology, Institute of Microbiology and Biotechnology, Maria Curie-Skłodowska University, Lublin, Poland; e-mail: majewska@poczta.umcs.lublin.pl
} 
Microbial immobilization of a HM from rhizosphere soil solution can involve binding of the metal by cell envelopes, its intracellular accumulation, formation of insoluble complexes with extracellular biopolymers or precipitation with inorganic anions, such as sulfides and phosphates (Kurek and Majewska, 2012). On the other hand, microorganisms can accelerate the decomposition of organic matter (e.g. dead roots) and, consequently, mobilize HM in the rhizosphere. Dissolved organic ligands (e.g. carboxylates and phenolics) exuded by plant roots and those produced by microorganisms are also responsible for HM mobilization. Soluble ligands which have a higher affinity for HM than roots and other solids, and those ligands which acidify the root zone are important factors in increasing HM desorption (Haoliang et al., 2007; Kim et al., 2010; Kurek and Majewska, 2012). These processes can increase HM concentrations in soil solution and decrease the capacity of phytostabilization.

The aim of the present study was to compare speciation of Cd (water-soluble, exchangeable absorbed and chelate-bound fractions) immobilized by roots of Festuca ovina grown at 1 or $10 \mu \mathrm{g} \mathrm{Cd} \mathrm{ml}{ }^{-1}$ of the growth medium. Also, the numbers of microorganisms inhabiting the growth medium and the root surface, and the concentrations of organic compounds (i.e. phenols, proteins, citric acid, reducing sugars, total Fe(III)chelators and siderophores) released by roots and/or root-associated microorganisms after three weeks of plant cultivation in both media were compared.

\section{Experimental}

\section{Materials and Methods}

Plant growth conditions. Half a gram of non-sterilized grass seeds (about 625) were transferred to sterile plastic sieves with a surface area of $170 \mathrm{~cm}^{2}$. The sieves were placed in sterile plastic containers $(2,000 \mathrm{ml})$ holding $600 \mathrm{ml}$ of autoclave-sterilized (non-aerated) Hoagland medium (Atlas, 1995; Sipos et al., 2013) supplemented with 1 or $10 \mu \mathrm{g} \mathrm{Cd} \mathrm{ml}{ }^{-1}$ (as $\mathrm{CdCl}_{2} \cdot 2.5 \mathrm{H}_{2} \mathrm{O}$ ). Cadmium-free Hoagland medium was used as a control. All glassware and plastic containers were soaked in $7.5 \mathrm{M} \mathrm{HNO}_{3}$ for at least $2 \mathrm{~h}$, rinsed thoroughly with deionized water and sterilized before use.

The plants were grown in a growth chamber (Biogenet, FD147 Inox) at $24 / 18^{\circ} \mathrm{C}$ (day/night), with a $12 / 12 \mathrm{~h}$ (day/night) photoperiod, at a photosynthetic photon flux density of $250 \mu \mathrm{mol} \mathrm{m} \mathrm{m}^{-2} \mathrm{~s}^{-1}$ for 3 weeks. The volume of the growth medium was kept constant by replenishing the volume evaporated during plant growth with sterile Hoagland medium without added Cd (Majewska and Kurek, 2011). After 3 weeks, 30 ran- domly-selected plants were removed from the medium and separated into roots and shoots. The roots were washed with sterile deionized water. Shoot height and root length as well as fresh and dry weight of the plants were determined. The dry weight of the plants was estimated after heating the plant material at $105^{\circ} \mathrm{C}$ until a constant weight was obtained.

Estimation of cadmium concentration in growth medium and in plants. The growth medium was collected and centrifuged $(9,000 \times \mathrm{g}$ for 15 minutes), and its $\mathrm{pH}$ was measured using a Beckman $\mathrm{pH}$-meter. The concentration of cadmium ions was determined using a cadmium ion selective electrode from SENTEK with a detection limit of $10^{-7} \mathrm{M}$. Next, $20 \mathrm{ml}$ of the medium was evaporated to dryness and digested with concentrated $\mathrm{HNO}_{3}$. In order to determine the concentration of the metal in shoots and roots, $30 \mathrm{mg}$ of dry plant material was digested with concentrated $\mathrm{HNO}_{3}$. Next, the acid was evaporated to dryness, and then the residue was dissolved in $10 \mathrm{ml}$ of $1 \mathrm{M} \mathrm{HNO}_{3}$ (Majewska et al., 2006). Cadmium concentrations were determined by mixing $1 \mathrm{ml}$ of mineralizate, $2 \mathrm{ml}$ of $3 \mathrm{M} \mathrm{NaOH}, 2 \mathrm{ml}$ of an aqueous solution of Triton X-100 (5\%) containing $0.3 \mathrm{mM}$ dithizone, and $5 \mathrm{ml}$ deionized water. The absorbance of the samples was determined at $\lambda=549$ $\mathrm{nm}$ using a Varian UV-visible spectrophotometer (Fiedler et al., 2004; Majewska and Kurek, 2011). The bioaccumulation factor (BAF) was calculated as $\mathrm{Cd}$ concentration in roots or shoots $\left(\mathrm{mg} \mathrm{kg}^{-1}\right)$ divided by the initial concentration of $\mathrm{Cd}$ in the medium $\left(\mathrm{mgl}^{-1}\right)$, and the translocation index (TRL) was described as $\mathrm{mg}$ $\mathrm{Cd} \mathrm{kg}^{-1}$ of dry weight of shoots divided by $\mathrm{mg} \mathrm{Cd} \mathrm{kg}{ }^{-1}$ of dry weight of roots (Mendez and Maier, 2008; Cheraghi et al., 2011).

Determination of dehydrogenase activity in root tissues. Metabolic activity in root tissues was assessed by the tetrazolium chloride (TTC) reduction method according to the procedure described by Comas et al. (2000). In the tissues, TTC was reduced to formazan (a bright-red pigment) by dehydrogenase enzymes. Roots (50 mg of fresh weight) were submerged in $3 \mathrm{ml}$ of $0.6 \%$ TTC in $0.05 \mathrm{M} \mathrm{Na}_{2} \mathrm{HPO}_{4}-\mathrm{KH}_{2} \mathrm{PO}_{4}$ buffer ( $\mathrm{pH} 7.4$ ) containing $0.05 \%$ Triton $\mathrm{X}-100$. The samples were incubated at $28^{\circ} \mathrm{C}$ for $24 \mathrm{~h}$, rinsed twice with distilled water, and extracted with $10 \mathrm{ml}$ of $95 \%$ ethanol for 10 minutes in a water bath at $85^{\circ} \mathrm{C}$. The total volume of the extract was made up to $25 \mathrm{ml}$, and the absorbance was measured at $\lambda=490 \mathrm{~nm}$ (Varian, UV-visible spectrophotometer). Control roots were boiled for 15 minutes in distilled water to denature the enzyme. Dehydrogenase activity in roots was expressed as $\mu \mathrm{g}$ of formazan formed by $1 \mathrm{mg}$ of root dry weight.

Sequential extraction of Cd immobilized in roots. After three weeks of plant growth, speciation of the metal immobilized by roots was analyzed using a three- 
step sequential extraction procedure. This method makes it possible to fractionate metals into fractions operationally defined as the water-soluble fraction (extracted with deionized water), the exchangeable absorbed fraction (extracted with $0.1 \mathrm{MNaNO}_{3}$ ) and the chelate-bound fraction (extracted with $0.02 \mathrm{M}$ EDTA). In addition, a residual fraction of cadmium, not removed during sequential extraction, was determined (Majewska and Kurek, 2011). Roots (500 mg fresh weight) were suspended in $100 \mathrm{ml}$ of each extractant and shaken (250 rotations per minute) at room temperature for 30 minutes. The extracts were evaporated to dryness, and Cd concentration was determined in the residues as described above. After sequential extraction, the roots were collected by filtration, dried and digested with $\mathrm{HNO}_{3}$, and the amount of $\mathrm{Cd}$ in root tissues was determined. Total cadmium concentrations as well as $\mathrm{Cd}$ ions were determined in all of the tested fractions as described above.

Determination of microorganisms CFU number. After three weeks of plant growth, the numbers of microorganisms in the growth medium, those released from the root surface during sequential extraction and those inhabiting interior root tissues were estimated by the plate count method. Fungi were cultivated on Martin medium (Martin, 1950) and bacteria on nutrient agar (Atlas, 1995) for 7 days at $28^{\circ} \mathrm{C}$. The number of microorganisms was expressed as $\log _{10}$ colony forming units (CFU) per milligram of dry weight root mass.

Determination of organic compound concentrations. Dissolved organic compounds, such as reducing sugars, proteins, phenols, citric acid, total Fe(III)chelators and siderophores were quantitated in water extracts and $0.1 \mathrm{M} \mathrm{NaNO}_{3}$ extracts from roots, and in the growth medium. Before determination of organic compounds, the plant growth medium was centrifuged $(9,000 \times \mathrm{g}$ for 15 minutes $)$. The amounts of reducing sugars were measured according to the method of Nelson and Somogyi (Alef and Nannipieri, 1995). Bradford reagent was used to determine protein concentrations, with albumin as a standard (Bradford, 1976). Total soluble phenolic compounds were measured by reaction with the Folin-Ciocalteau reagent, and calibration was performed using ferulic acid as a standard (de Ascencao and Dubery, 2003). Citric acid was determined using a commercial kit (R-BIOPHARM Enzymatic Bioanalysis, Cat. No 10139 076 035). Reactions with $\mathrm{FeCl}_{3}$ were carried out to estimate the total amount of organic $\mathrm{Fe}(\mathrm{III})$-chelators. In this method, desferrioxamine B was used to construct the calibration curve (Atkin et al., 1970). Catechol and hydroxamate siderophores were determined by the Arnow method with 3,4-dihydroxybenzoic acid as a standard (Arnow, 1937) and the Csaky method with hydroxylamine hydrochloride (Csaky, 1948), respectively.
Data analysis. Three experimental settings were used for each treatment $\left(0,1\right.$ and $10 \mu \mathrm{g} \mathrm{Cd} \mathrm{ml}{ }^{-1}$ of growth medium), and the experiment was performed three times. One-way analysis of variance was carried out to compare the mean values. When significant $p$-values were obtained $(p<0.05)$, differences between the individual means were compared using Student's t-test (Brandt, 1999). All data analyses were performed using Microsoft ${ }^{\oplus}$ Excel 2010.

\section{Results}

Plant growth and dehydrogenase activity under different Cd concentrations. Symptoms of cadmium toxicity to grass seedlings were developed 3 weeks after the treatments, especially in the presence of $10 \mu \mathrm{g}$ $\mathrm{Cd} \mathrm{ml}^{-1}$ in the growth medium. Yellow lesions on shoots and dark-brown root tips were found. Cd concentration in the growth medium did not affect the number of plants surviving at the end of the experiment (Table I). Plant growth, expressed as shoot height and shoot fresh weight, was significantly inhibited when the plants were exposed to $1 \mu \mathrm{g} \mathrm{Cd} \mathrm{ml}{ }^{-1}$. Cd had a stronger effect on shoots than on roots (Table I). No significant reduction in fresh and dry weights and length of roots in the presence of $1 \mu \mathrm{g} \mathrm{Cd} \mathrm{ml}{ }^{-1}$ was observed. Inhibition of plant growth by $10 \mu \mathrm{g} \mathrm{Cd} \mathrm{ml}^{-1}$ of the medium was much more severe than that caused by $1 \mu \mathrm{g} \mathrm{Cd} \mathrm{ml}{ }^{-1}$. The activity of dehydrogenase enzymes in root tissues declined with the increase in $\mathrm{Cd}$ concentration in the growth medium (Table I). The highest decrease in the activity of these enzymes was observed in roots of plants cultivated in the presence of $10 \mu \mathrm{g} \mathrm{Cd} \mathrm{ml}{ }^{-1}$.

Cd concentrations in shoots and roots. The concentration of cadmium immobilized by the plant biomass increased with the increase in Cd concentration in the growth medium, and was always higher in roots than in shoots. Cd concentration in roots of plants grown at $1 \mu \mathrm{g} \mathrm{Cd} \mathrm{ml} l^{-1}$ was approximately three times lower than in roots of plants grown in the medium containing $10 \mu \mathrm{g} \mathrm{Cd} \mathrm{ml}^{-1}$ whereas for shoots this difference was almost 10 -fold (Table I). The value of the bioaccumulation factor (BAF) for roots of plants cultivated in the medium containing $10 \mu \mathrm{g} \mathrm{Cd} \mathrm{ml}{ }^{-1}$ was significantly lower than for those grown at $1 \mu \mathrm{g}$ $\mathrm{Cd} \mathrm{ml}^{-1}$. On the other hand, there was no significant difference between the values of BAF for shoots from the two treatments (Table I). Cadmium concentration in the growth medium significantly affected the values of TRL. For plants cultivated in the growth medium at $10 \mu \mathrm{g} \mathrm{Cd} \mathrm{ml} l^{-1}$, TRL was 3.5 times higher than for plants cultivated at $1 \mu \mathrm{g} \mathrm{Cd} \mathrm{ml} l^{-1}$ (Table I).

Concentrations of $\mathrm{Cd}$ in the growth medium and in the individual fractions of the root extraction. At 
Table I

Effect of Cd on F. ovina growth parameters, dehydrogenase activity and Cd accumulation in its roots and shoots. Mean values with marked the same letter within the same row do not differ significantly $(p>0.05)$. Values are expressed as mean \pm S.D. $(n=9)$

\begin{tabular}{|c|c|c|c|c|}
\hline \multirow{2}{*}{\multicolumn{2}{|c|}{ Parameters }} & \multicolumn{3}{|c|}{ Cadmium concentration in the growth medium $\left(\mu \mathrm{g} \mathrm{ml}^{-1}\right)$} \\
\hline & & 0 & 1 & 10 \\
\hline \multicolumn{2}{|l|}{ Number of plants } & $509 \pm 27 a$ & $536 \pm 41 \mathrm{a}$ & $505 \pm 28 \mathrm{a}$ \\
\hline \multicolumn{2}{|l|}{ Shoot height $(\mathrm{mm})$} & $95 \pm 9 \mathrm{a}$ & $63 \pm 19 b$ & $49 \pm 14 b$ \\
\hline \multicolumn{2}{|l|}{ Root length (mm) } & $91 \pm 30 \mathrm{a}$ & $65 \pm 31 \mathrm{a}$ & $16 \pm 7 b$ \\
\hline \multirow[t]{2}{*}{$\begin{array}{l}\text { FW (mg) } \\
\text { Biomass of } 100 \text { plants }\end{array}$} & Shoots & $\begin{array}{c}1046 \pm 106 \mathrm{a} \\
(100 \%)\end{array}$ & $\begin{array}{c}700 \pm 76 b \\
(67 \%)\end{array}$ & $\begin{array}{c}297 \pm 48 c \\
(28 \%)\end{array}$ \\
\hline & Roots & $\begin{array}{c}501 \pm 68 \mathrm{a} \\
(100 \%)\end{array}$ & $\begin{array}{c}602 \pm 81 \mathrm{a} \\
(120 \%)\end{array}$ & $\begin{array}{c}53 \pm 14 b \\
(11 \%)\end{array}$ \\
\hline \multirow[t]{2}{*}{$\begin{array}{l}\text { DW (mg) } \\
\text { Biomass of } 100 \text { plants }\end{array}$} & Shoots & $\begin{array}{c}148 \pm 16 \mathrm{a} \\
(100 \%)\end{array}$ & $\begin{array}{c}128 \pm 9 a \\
(86 \%)\end{array}$ & $\begin{array}{c}79 \pm 1 c \\
(53 \%)\end{array}$ \\
\hline & Roots & $\begin{array}{l}57 \pm 11 \mathrm{a} \\
(100 \%)\end{array}$ & $\begin{array}{c}58 \pm 20 \mathrm{a} \\
(102 \%)\end{array}$ & $\begin{array}{c}24 \pm 6 b \\
(42 \%)\end{array}$ \\
\hline \multicolumn{2}{|c|}{ Activity of root dehydrogenase ( $\mu \mathrm{g}$ formazan $\mathrm{mg}^{-1} \mathrm{DW}$ ) } & $2.78 \pm 0.74 \mathrm{a}$ & $1.58 \pm 0.96 \mathrm{a}$ & $0.52 \pm 0.16 b$ \\
\hline \multirow[t]{2}{*}{ Cd concentration $\left(\mu \mathrm{g} \mathrm{Cd} \mathrm{\textrm {mg } ^ { - 1 } \mathrm { DW } )}\right.$} & Shoots & 0 & $0.07 \pm 0.01 \mathrm{~b}$ & $0.76 \pm 0.17 \mathrm{a}$ \\
\hline & Roots & 0 & $1.74 \pm 0.18 b$ & $5.39 \pm 0.30 \mathrm{a}$ \\
\hline \multirow[t]{2}{*}{ BAF } & Shoots & - & $71 \pm 12 a$ & $76 \pm 17 a$ \\
\hline & Roots & - & $1742 \pm 188 \mathrm{a}$ & $539 \pm 35 b$ \\
\hline \multicolumn{2}{|l|}{ TRL } & - & $0.04 \pm 0.01 \mathrm{~b}$ & $0.14 \pm 0.04 \mathrm{a}$ \\
\hline
\end{tabular}

- not determined, FW - fresh weight, DW - dry weight, BAF - bioaccumulation factor, TRL - translocation index

Table II

Distribution of Cd between plant biomass (Cd bioaccumulation), sediment (Cd precipitation) and growth medium (soluble complexes and ionic form of $\mathrm{Cd}$ ) after 3-week cultivation of F. ovina in the hydroponic system. Values are expressed as mean \pm S.D. $(n=9)$

\begin{tabular}{|c|c|c|c|}
\hline \multirow{2}{*}{\multicolumn{2}{|c|}{ Parameters }} & \multicolumn{2}{|c|}{$\begin{array}{l}\text { Cadmium concentration in growth medium } \\
\qquad\left(\mu \mathrm{g} \mathrm{ml}^{-1}\right)\end{array}$} \\
\hline & & 1 & 10 \\
\hline \multicolumn{2}{|c|}{ Initial amount of Cd in the hydroponic system $(\mu \mathrm{g})$} & $527 \pm 52(100 \%)$ & $5917 \pm 42(100 \%)$ \\
\hline \multicolumn{2}{|c|}{ Amount of Cd accumulated by plants } & $357 \pm 41(64 \%)$ & $841 \pm 67(16 \%)$ \\
\hline \multicolumn{2}{|c|}{ Amount of Cd in sediment (insoluble forms of Cd) } & $35 \pm 2(6 \%)$ & $661 \pm 112(13 \%)$ \\
\hline \multirow[t]{2}{*}{ Amount of Cd in growth medium } & Ionic form & $17 \pm 3(3 \%)$ & $3550 \pm 148(60 \%)$ \\
\hline & Non-ionic form & $147 \pm 3(27 \%)$ & $687 \pm 48(11 \%)$ \\
\hline
\end{tabular}

$1 \mu \mathrm{g} \mathrm{Cd} \mathrm{ml} \mathrm{g}^{-1}$, plants accumulated $64 \%$ of Cd present in the growth medium, $6 \%$ was converted to insoluble forms, which were separated by centrifugation, and $30 \%$ of Cd remained in the growth medium. The metal in the medium was either in the ionic form or bound to soluble compounds (Table II). When the concentration of Cd was increased to $10 \mu \mathrm{g} \mathrm{Cd} \mathrm{ml} \mathrm{gl}^{-1}, 16 \%$ of the metal was accumulated in the plant biomass, $13 \%$ was stored as insoluble forms and $71 \%$ was still found in the medium, primarily in the ionic form (Table II).

A three-step sequential extraction of the Cd immobilized by grass roots was applied to evaluate the participation of the dissolution (fraction 1, Cd extracted with deionized water), ionic exchange (fraction 2,
Cd extracted with $0.1 \mathrm{M} \mathrm{NaNO}_{3}$ ) and chelation (fraction 3, Cd extracted with $0.02 \mathrm{M}$ EDTA) processes, as well as intracellular accumulation (fraction 4, residual Cd) in cadmium immobilization by roots of sheep's fescue plants. When Cd concentration in the medium was $1 \mu \mathrm{g} \mathrm{ml}^{-1}$, 9\% was extracted with deionized water, $20 \%$ was extracted with $0.1 \mathrm{M} \mathrm{NaNO}_{3}$ and $28 \%$ with $0.02 \mathrm{M}$ EDTA (Fig. 1B). The increase in metal concentration in the medium from 1 to $10 \mu \mathrm{g} \mathrm{Cd} \mathrm{ml}{ }^{-1}$ resulted in an elevated concentration of $\mathrm{Cd}$ in all the fractions tested (Fig. 1A). The percentage distribution of Cd between the fractions was also changed: it increased in the watersoluble (12\%) and ionic exchange (25\%) fractions and decreased in the fraction extracted with $0.02 \mathrm{M}$ EDTA 
A

$\mathrm{Cd}$ concentration in particulr fractions

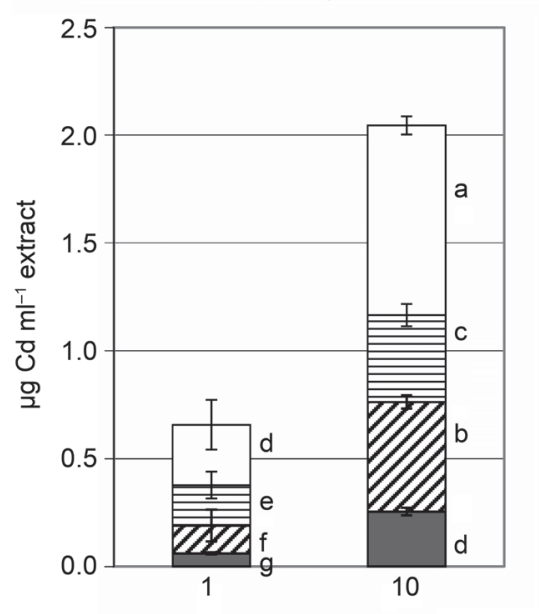

$B$

Percentade distribution of $\mathrm{Cd}$

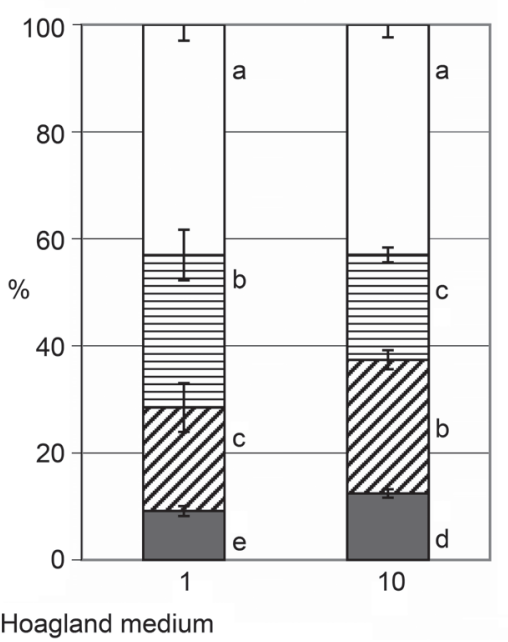

1 - water-soluble fraction (Cd extracted with deionized water) 2 - exchangeable absorbed fraction (Cd extracted with $0.1 \mathrm{M} \mathrm{NaNO}_{3}$ )

3 - chelate-bound fraction (Cd extracted with $0.02 \mathrm{M}$ EDTA) 4 - residual fraction ( $\mathrm{Cd}$ extracted with concentrated $\mathrm{HNO}_{3}$ )

$\mu \mathrm{g} \mathrm{Cd} \mathrm{ml}{ }^{-1}$ of Hoagland medium

Fig. 1. Sequential extraction of Cd immobilized by roots of F. ovina after 3-week cultivation in Hoagland's growth medium supplemented with 1 or $10 \mu \mathrm{g} \mathrm{Cd} \mathrm{ml}{ }^{-1}$.

A - concentration of $\mathrm{Cd}$ in the individual fractions ( $\mu \mathrm{g} \mathrm{Cd}$ per $1 \mathrm{ml}$ of extract); B - percentage distribution of Cd between the fractions tested. Bars marked with the same letter are not significantly different $(p>0.05)$. Standard deviations are shown as deviation bars $(n=9)$

(20\%) (Fig. 1B). At both Cd concentrations in the growth medium, the roots of the grass accumulated an average of $43 \%$ of the immobilized metal in their tissues.

Cadmium extracted from roots was released as metal bound to soluble organic compounds and as free ions. When the metal was extracted with $0.02 \mathrm{M}$ EDTA, the whole pool of cadmium removed was bound to EDTA in both treatments. At $1 \mu \mathrm{g} \mathrm{Cd} \mathrm{ml}{ }^{-1}, 12.3 \%$ of the metal extracted from roots with $0.1 \mathrm{M} \mathrm{NaNO}_{3}$ was in the ionic form, whereas at $10 \mu \mathrm{g} \mathrm{Cd} \mathrm{ml}{ }^{-1}$, as much as $48.5 \%$ of Cd was present in the extracts in this form. No cadmium ions were found in water extracts from roots of plants grown at $1 \mu \mathrm{g} \mathrm{Cd} \mathrm{ml} l^{-1}$, but at $10 \mu \mathrm{g} \mathrm{Cd} \mathrm{m}^{-1}$, about $7.1 \% \mathrm{Cd}$ was in the ionic form (data not presented).

Concentrations of organic compounds. Sheep's fescue grass reacted to the presence of cadmium in the growth medium with an increased release of organic compounds from roots into the growth medium. After plant cultivation, the growth medium supplemented with $10 \mu \mathrm{g} \mathrm{Cd} \mathrm{ml} l^{-1}$, was enriched 3-fold with total chelators and citric acid, 4-fold with catechol siderophores and 5-fold with hydroxamate siderophores, proteins and reducing sugars compared to the control medium without added metal. At $1 \mu \mathrm{g} \mathrm{Cd} \mathrm{ml}{ }^{-1}$, the growth medium was significantly enriched with catechol siderophores, proteins and reducing sugars only (Table III). Also, the amounts of total chelators, siderophores, proteins and reducing sugars extracted with deionized water and $0.1 \mathrm{M} \mathrm{NaNO}_{3}$ from root surfaces were increased, but the amount of citric acid dropped with the increase in $\mathrm{Cd}$ concentration in the growth medium (Fig. 2). The solution of $\mathrm{NaNO}_{3}$ mobilized more organic compounds from roots than did deionized water, except for total chelators and citric acid, which were efficiently released

Table III

Organic compounds in the growth medium after 3-week cultivation of F. ovina in Hoagland medium. The amounts of the individual compounds are expressed as $\mu \mathrm{g} \mathrm{mg}^{-1} \mathrm{dry}$ weight of roots. Mean values marked with the same letter within the same row do not differ significantly $(p>0.05)$. Values are expressed as mean \pm S.D. $(n=9)$

\begin{tabular}{|l|c|c|c|}
\hline \multirow{2}{*}{\multicolumn{1}{c|}{ Organic compounds }} & \multicolumn{3}{c|}{ Cd in the growth medium $\left(\mu g \mathrm{Cd} \mathrm{ml}^{-1}\right)$} \\
\cline { 2 - 4 } & 0 & 1 & 10 \\
\hline Total chelators & $3.43 \pm 0.41 \mathrm{~b}$ & $4.24 \pm 0.31 \mathrm{~b}$ & $11.54 \pm 1.74 \mathrm{a}$ \\
\hline Hydroxamate siderophores & $2.14 \pm 1.53 \mathrm{~b}$ & $2.65 \pm 0.46 \mathrm{~b}$ & $10.01 \pm 4.06 \mathrm{a}$ \\
\hline Reducing sugars & $2.31 \pm 0.56 \mathrm{~b}$ & $7.13 \pm 1.67 \mathrm{a}$ & $11.84 \pm 4.08 \mathrm{a}$ \\
\hline Phenols & $0.25 \pm 0.01 \mathrm{a}$ & $0.98 \pm 0.16 \mathrm{a}$ & 0 \\
\hline Citric acids & $0.90 \pm 0.36 \mathrm{~b}$ & $1.00 \pm 0.18 \mathrm{~b}$ & $2.62 \pm 0.47 \mathrm{a}$ \\
\hline Proteins & $0.72 \pm 0.53 \mathrm{~b}$ & $3.48 \pm 0.62 \mathrm{a}$ & $3.81 \pm 2.32 \mathrm{a}$ \\
\hline Catechol siderophores & $1.50 \pm 0.48 \mathrm{c}$ & $2.88 \pm 0.18 \mathrm{~b}$ & $5.58 \pm 0.40 \mathrm{a}$ \\
\hline
\end{tabular}



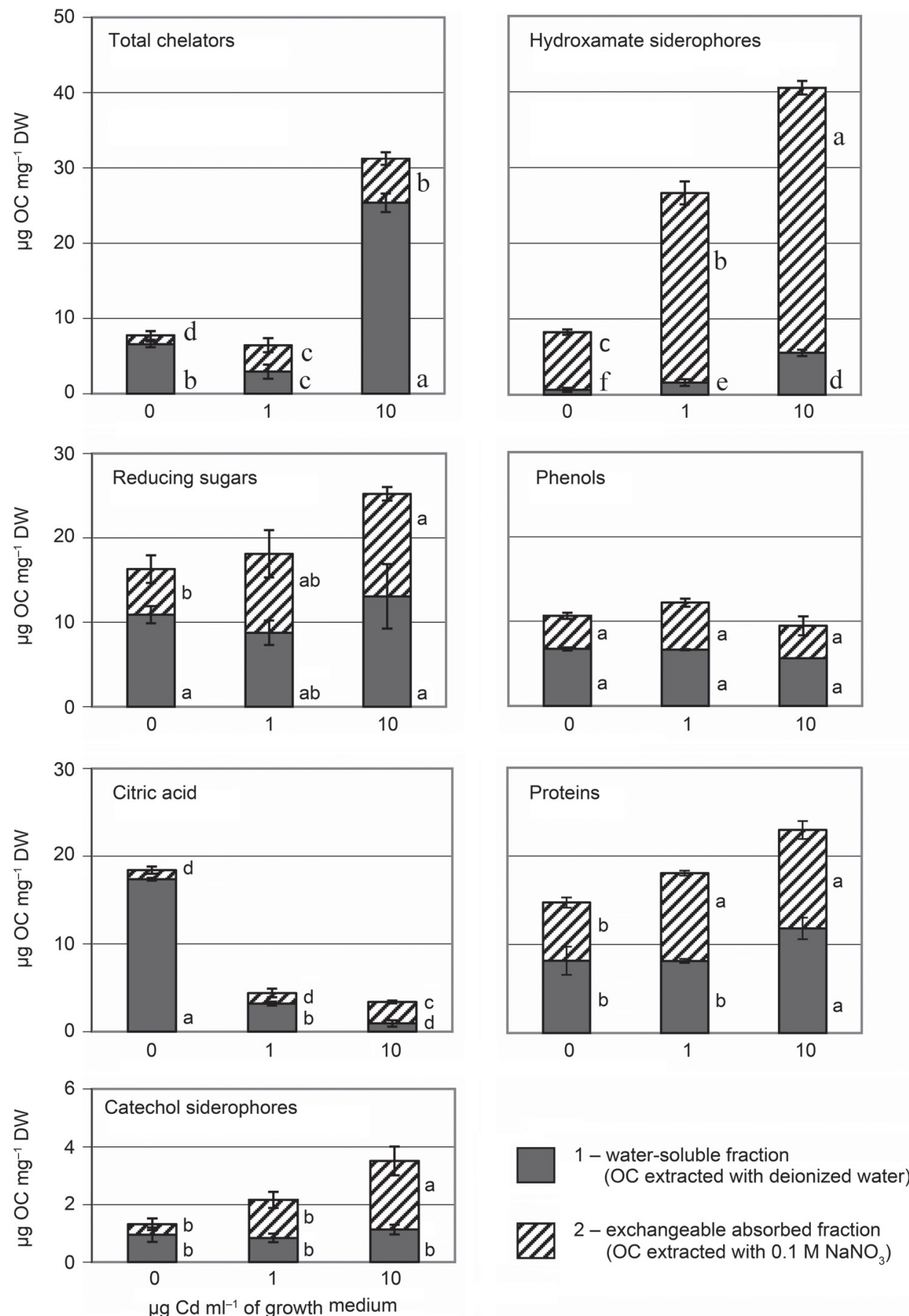

Fig. 2. Two-step sequential extraction of organic compounds (OC) from roots of F. ovina after 3-week cultivation in Hoagland's growth

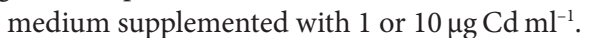

The amounts of the individual compounds are expressed as $\mu \mathrm{g} \mathrm{OC} \mathrm{mg}^{-1}$ dry weight of roots. Bars marked with the same letter are not significantly different $(p>0.05)$. Standard deviations are shown as deviation bars $(n=9)$

to the water fraction. There were no differences between the treatments in the amounts of phenols extracted from roots.

Microorganisms colonizing grass roots and the growth medium. After three-week cultivation of plants, a microbiological analysis of the plant growth media and the extracts obtained during sequential extraction of plant roots was performed. Regardless of Cd concentration in the growth medium, bacteria were the only microorganisms isolated. The number of bacteria in the growth medium without $\mathrm{Cd}$ added was significantly lower than in the medium supplemented with 1 or $10 \mu \mathrm{g} \mathrm{Cd} \mathrm{ml} l^{-1}$ (Table IV). After sequential extraction of plant roots cultivated in Cd-contaminated media, the number of bacteria in the water and $0.1 \mathrm{M} \mathrm{NaNO}_{3}$ extracts was significantly higher than in extracts from control roots (without added Cd). The concentration of $\mathrm{Cd}$ was without effect on the number of bacteria 
Table IV

The number of bacteria in the growth medium and four sequential extraction fractions obtained from F. ovina roots (log CFU mg $^{-1} \mathrm{DW}$ of roots). Mean values marked with the same letter within a column do not differ significantly $(p>0.05)$. Values are expressed as mean \pm S.D. $(n=9)$

\begin{tabular}{|c|c|c|c|c|c|}
\hline \multirow{2}{*}{$\begin{array}{c}\text { Cd concentration } \\
\text { in Hoagland } \\
\text { medium }\left(\mu \mathrm{g} \mathrm{Cd} \mathrm{ml}^{-1}\right)\end{array}$} & $\begin{array}{c}\text { Bacteria } \\
\text { in Hoagland } \\
\text { medium }\end{array}$ & $\begin{array}{c}\text { Fraction 1 extracted } \\
\text { with } \mathrm{H}_{2} \mathrm{O}\end{array}$ & $\begin{array}{c}\text { Fraction 2 extracted } \\
\text { with NaNO }\end{array}$ & $\begin{array}{c}\text { Fraction 3 extracted } \\
\text { with EDTA }\end{array}$ & $\begin{array}{c}\text { Fraction } 4 \text { inhabiting } \\
\text { root tissues }\end{array}$ \\
\cline { 3 - 6 } & $5.60 \pm 0.12 \mathrm{~b}$ & $5.95 \pm 0.27 \mathrm{~b}$ & $4.92 \pm 0.06 \mathrm{~b}$ & $5.13 \pm 0.32 \mathrm{a}$ & $5.62 \pm 0.05 \mathrm{a}$ \\
\hline 0 & $6.02 \pm 0.01 \mathrm{a}$ & $6.72 \pm 0.21 \mathrm{a}$ & $5.89 \pm 0.06 \mathrm{a}$ & $4.96 \pm 0.11 \mathrm{a}$ & $5.23 \pm 0.16 \mathrm{a}$ \\
\hline 1 & $6.69 \pm 0.37 \mathrm{a}$ & $6.96 \pm 0.28 \mathrm{a}$ & $5.96 \pm 0.03 \mathrm{a}$ & $5.28 \pm 0.10 \mathrm{a}$ & $3.09 \pm 0.21 \mathrm{~b}$ \\
\hline 10 & & &
\end{tabular}

released during extraction of roots with $0.02 \mathrm{M}$ EDTA. The number of bacteria isolated from root tissues after sequential extraction was significantly decreased when Cd concentration in the plant growth medium was increased (Table IV). The water fraction was the richest in bacteria. At the concentration of $10 \mu \mathrm{g} \mathrm{Cd} \mathrm{ml} l^{-1}$, the number of bacteria on the root surface (extracted with water) was 10,000 higher than the number of bacteria isolated from root tissues. Release of microbial and plant metabolites into the growth medium during cultivation of the plants resulted in a decrease in $\mathrm{pH}$ values from $6.6 \pm 0.1$ to $5.8 \pm 0.3$ regardless of the concentration of $\mathrm{Cd}$ added.

\section{Discussion}

The root surface is a site of very important processes involved in plant growth and of interactions between organic compounds and microorganisms. These interactions affect biogeochemical cycling, enhancing plant growth, and increase plant tolerance to biotic and abiotic stress (Kamaludeen and Ramasamy, 2008; Philippot et al., 2013). In the present study, the grass F. ovina (var. Bornito - a commercially available cultivar) was used because of its resistance to drought and nutrient deficiency and because it does not require special soil conditions (as noted on packet). This choice was also influenced by observations of Grodzińska and SzarekŁukaszewska (2009), who had found that F. ovina was one of the dominant plant species on postindustrial waste heaps containing zinc, lead, cadmium, thallium and other metals.

Cadmium tends to be more labile in soil and more available to plants than other divalent metals (Kacálková et al., 2014). An et al. (2011) compared the accumulation of $\mathrm{Cd}, \mathrm{Pb}, \mathrm{Cu}, \mathrm{Cr}$ and $\mathrm{Fe}$ in different plant species (tomato, maize, greengrocery, cabbage and Japanese clover herb). Among the metals tested, cadmium was easily absorbed and had the highest enrichment coefficient values for most plant tissues. In the present study, the values of the Cd bioaccumulation factor (BAF) calculated for roots of F. ovina growing at 1 or
$10 \mu \mathrm{g} \mathrm{Cd} \mathrm{ml}^{-1}$ of hydroponic solution were very high (1742 and 539, respectively) because metal retention by soil solid components was eliminated. Cadmium concentration was always higher in roots of F. ovina than in its shoots and increased with the elevated $\mathrm{Cd}$ concentration in the growth medium. A comparison of cadmium accumulation in roots and shoots of other grasses, such as Lolium perenne (Lou et al., 2013), Elymus elongatus (Sipos et al., 2013) and Secale cereale (Majewska and Kurek, 2011), also shows that roots tend to contain more of this metal than shoots. Mendez and Maier (2008), Cheraghi et al. (2011) and Zhang et al. (2012) have recommended plants (monocotyledons and dicotyledons) with a high $\operatorname{BAF}(>1)$ and a low translocation index $(\mathrm{TRL}<1)$ as the best candidates for phytostabilization. The values of TRL for F. ovina growing at $1 \mu \mathrm{g} \mathrm{ml}^{-1}$ as well as at $10 \mu \mathrm{g} \mathrm{ml}^{-1}$ were much lower than 1 ( 0.04 and 0.14 , respectively). The same situation was observed in F. ovina growing at 5, 10, 50 and $100 \mu \mathrm{g} \mathrm{Cd} \mathrm{g}{ }^{-1}$ dry weight of soil (data unpublished).

The exposure of F. ovina to $10 \mu \mathrm{g} \mathrm{Cd} \mathrm{ml}^{-1}$ resulted in a significant decrease in shoot height, root length, fresh and dry mass of the plants, and vitality of plant roots, while at $1 \mu \mathrm{g} \mathrm{ml}^{-1}$ these parameters were not significantly changed (Table I). This indicates that low concentrations of $\mathrm{Cd}$ may have no impact on plants. In the present study, the vitality of plant roots was determined by measuring dehydrogenase activity expressed as TTC reduction. According to Comas et al. (2000), there is a relationship between respiration and dehydrogenase activity, and respiration is a standard test of metabolic activity of cells. A low TTC reduction can be indicative of a generally low metabolic activity or necrosis of root tissues. TTC reduction can be evaluated in the stele but not in the cortex of old roots. Heavy metal toxicity can accelerate the senescence and death of roots and can cause a decline in root function. In these cases, roots can only adsorb metals on their surface without transporting them into root tissue cells and translocating them into shoots.

Another reaction of the grass's roots to Cd treatment was an increased release of organic compounds to the growth medium and their storage on the root sur- 
face. Numerous authors have observed that Cd-stress induces changes in plant metabolism, with plants synthesizing concentrations of organic compounds that are significantly higher than those synthesized by plants growing in unpolluted environments (dell'Amico et al., 2005; Madhaiyan et al., 2007; Adeniji et al., 2010; Kim et al., 2010). Li et al. (2014) have reported that exudation of high amounts of dissolved organic carbon by roots of Triticum aestivum is an important protective mechanism under Cd stress. In our study, after cultivation of F. ovina, the growth medium contaminated with $10 \mu \mathrm{g} \mathrm{Cd} \mathrm{ml}{ }^{-1}$ was significantly enriched with various organic chelators, siderophores, citric acid, reducing sugars and different proteins (Table III). By contrast, the amounts of phenols in the growth medium decreased to zero at this Cd dose. This drop could have been caused by accumulation of soluble phenolics in root cells and their use in the phenylpropanoid (phenyloalanine) pathway connected with induction of plant resistance to different biotic and abiotic stresses (Atkinson and Urwin, 2012; Khan et al., 2015; Zhang et al., 2015). One of the main results of the induction of this pathway is lignin biosynthesis, which leads to straightening of the plant cell wall by its lignification (Schützendüdel et al., 2001; Elobeid et al., 2012). Acceleration of cell wall lignification under Cd-stress can, on the one hand, negatively affect root elongation, but, on the other, increase Cd immobilization and detoxification, and ultimately enhance tolerance of the plants to this metal.

The exposure of sheep's fescue to $10 \mu \mathrm{g} \mathrm{Cd} \mathrm{ml}{ }^{-1}$ also significantly increased the amounts of organic compounds, other than citric acid, attached to the root surface (Fig. 2). A similar increase has been observed for S. cereale cultivated in the same conditions (Majewska and Kurek, 2011). The thick layer of organic material developing on the root surface acted as the first barrier against $\mathrm{Cd}$ entering into root tissues while organic compounds secreted into the growth medium played an important role in decreasing the concentration of free metal ions. After F. ovina cultivation, only part of the $\mathrm{Cd}$ introduced into the hydroponic solution remained in the medium in the ionic form (Table II).

Non-sterilized grass seeds were used in the experiments. The microbial community of these seeds inhabited the growth medium and the root surface of cultivated plants (Table IV). Proliferation of microorganisms was stimulated in the presence of organic compounds, which were efficiently released by roots of plants growing at $10 \mu \mathrm{g} \mathrm{Cd} \mathrm{ml}^{-1}$. The numbers of bacteria in the growth medium were significantly higher at $10 \mu \mathrm{g} \mathrm{Cd} \mathrm{ml}{ }^{-1}$ than in the control medium without cadmium. Also, the numbers of bacteria attached to the root surface and removed during extraction were the highest at $10 \mu \mathrm{g} \mathrm{Cd} \mathrm{ml}^{-1}$. Fungi were found neither in the growth medium nor on the root surface in either of the Cd treatments. The numbers of bacteria isolated from F. ovina roots after extraction declined with the increase in $\mathrm{Cd}$ concentration in the growth medium, and at $10 \mu \mathrm{g} \mathrm{Cd} \mathrm{m}^{-1}$ their titer was two orders of magnitude lower than at $1 \mu \mathrm{g} \mathrm{Cd} \mathrm{ml}{ }^{-1}$ (Table IV). In the natural environment, plant roots are always associated with microorganisms, which utilize organic compounds released to the root zone and produce their own metabolites. Endophytes (strains inhabiting the internal tissues of plants), such as Serratia nematodiphila, Enterobacter aerogenes, Enterobacter sp. or Acinetobacter sp. (Chen et al., 2010), and rhizosphere bacteria, such as those belonging to the genera Agrobacterium, Arthrobacter, Mycobacterium, Pseudomonas (dell'Amico et al., 2005), Burkholderia and Methylobacterium (Madhaiyan et al., 2007), could protect plants from the toxic effect of metals (biosorption and precipitation), produce plant growth-promoting compounds (indole acetic acid, siderophores and ACC-deaminase) and improve $\mathrm{Fe}$ and $\mathrm{P}$ nutrition. In contaminated habitats, some sensitive microbes would be eliminated while others would develop resistance to heavy metals and proliferate. Kao et al. (2006), for example, have demonstrated that microorganisms adapted to high $\mathrm{Zn}, \mathrm{Cu}$ and $\mathrm{Pb}$ concentrations in soil, and that their respiration, expressed as $\mathrm{CO}_{2}$ production, strongly increased within 7 days after metal supplementation.

Cadmium applied at the concentrations of 1 and $10 \mu \mathrm{g} \mathrm{ml}^{-1}$ of the growth medium was immobilized by F. ovina roots in different amounts (1.7 and $5.4 \mathrm{mg} \mathrm{g}^{-1}$, respectively). Roots are composed of many different compounds which are responsible for immobilization of metals. Chen et al. (2013) have suggested that pectin and cellulose, but not hemicellulose, present in the cell walls of Salix jiangsuensis J172 were responsible for Cd adsorption. Next to cellulose, the most abundant natural raw material is lignin. Lignin is an aromatic polymer which contains several functional groups, e.g. methoxyl, aliphatic and phenolic hydroxyl, and carboxyl groups, that can act as very efficient binding agents in the immobilization of heavy metal ions (Šćiban et al., 2011). The results of the present study revealed that $43 \%$ of Cd immobilized by the roots of plants grown at both cadmium concentrations was retained in their tissues and not released during sequential extraction (Fig. 1). Yin et al. (2015), in a study of Boehmeria nivea, have recorded the highest concentration of $\mathrm{Cd}$ in the cytoderm fraction (precipitated Cd or Cd bound in cell walls), which was found to be the most stable fraction of the metal in plant tissues. This metal could be mobilized only after cell lysis and microbial mineralization of dead tissues. The remaining part of Cd immobilized by F. ovina roots was loosely bound (deionized water extractable metal), exchangeably bound (extracted with $0.1 \mathrm{M} \mathrm{NaNO}_{3}$ ) and bound by chelation (Cd extracted 
with 0.02 MEDTA). Cadmium mobilized by deionized water and $0.1 \mathrm{M} \mathrm{NaNO}_{3}$ solution with an ionic strength equal to the strength of soil solution is considered to be the most labile. Cadmium extracted with EDTA is strongly bound and difficult to remove by soil solution (Kurek and Majewska, 2004). The increase in $\mathrm{Cd}$ concentration in the medium from 1 to $10 \mu \mathrm{g} \mathrm{ml}^{-1}$ resulted in elevated amounts of $\mathrm{Cd}$ extracted from roots with deionized water and $0.1 \mathrm{MNaNO}_{3}$, and decreased amounts of Cd extracted with 0.02 M EDTA (Fig. 1B), which means that the stability of $\mathrm{Cd}$ immobilized by roots was weakened.

Cadmium extracted from F. ovina roots was released as free ions and as metal bound to soluble organic compounds. Metal-organic complexes present in the root zone have different degrees of toxicity, bioavailability and degradation. It has been proven that the rate of mineralization of metal-organic complexes such as $\mathrm{Cd}$-acetate and Cd-citrate was significantly lower than for complexes with $\mathrm{Mg}$ or $\mathrm{Zn}$ (Renella et al., 2004). In such cases, metal-organic complexes can be incorporated into the soil organic matter during humification and humus accumulation. In the natural environment, microbiological decomposition of plant residues is a source of substrates for the synthesis of macromolecular polymers that are combined into aggregates of humic substances (Semenov et al., 2013). If grass shoots with a low Cd concentration $\left(\sim 0.76 \mu \mathrm{g} \mathrm{mg}^{-1} \mathrm{DW}\right)$ return to the soil as plant residues, they could facilitate humification and efficiently increase metal stabilization in re-vegetated soils. Further studies are required, however, to fully understand the mechanisms of HM phytostabilization in contaminated soils.

\section{Conclusion}

In order to exclude $\mathrm{Cd}$ retention by soil solid components, hydroponic cultures were chosen for the experiments. The results of the present study show that Cd-stress decreased F. ovina biomass, shoot height, root length and root activity but increased the quantity of root exudates, especially at $10 \mu \mathrm{g} \mathrm{ml}^{-1}$ of the growth medium. At this $\mathrm{Cd}$ concentration, root exudates containing organic chelators, siderophores, proteins and reducing sugars significantly stimulated proliferation of bacteria introduced into the hydroponic solution with non-sterilized seeds. Fungi were not detected.

F. ovina immobilized $\mathrm{Cd}$ in roots $(\mathrm{BAF}=539)$, with a very low translocation of this metal to shoots $(\mathrm{TRL}=0.14)$. Therefore, this grass could be potentially used for phytostabilization of metals in contaminated soils. Cadmium immobilized by roots was released during sequential extraction as free ions or in a form bound with organic compounds. These observations suggest that the dissolution, ion exchange and chelation processes occurring in the close vicinity of roots can release $\mathrm{Cd}$ immobilized in those roots. The root zone is a specific habitat created by root exudates and microorganisms, and mechanisms controlling Cd phytostabilization are difficult to determine precisely due to the multiple factors acting in this zone.

\section{Acknowledgements}

This work was financially supported by grant no. N N305 336334 from the Polish Ministry of Science and Higher Education.

\section{Literature}

Adeniji B.A., M.T. Budimir-Hussey and S.M. Macfie. 2010. Production of organic acids and adsorption of Cd on roots of durum wheat (Triticum turgidum L. var. durum). Acta Physiol. Plant. 32: 1063-1072.

Alef K. and P. Nannipieri. 1995. Methods in applied soil microbiology and biotechnology. Academic Press, London.

Alvarenga P., A.P. Gonçalves, R.M. Fernandes, A. de Varennes, G. Vallini, E. Duarte and A.C. Cunha-Queda. 2008. Evaluation of composts and liming materials in the phytostabilization of a mine soil using perennial ryegrass. Sci. Total Environ. 406: 43-56.

An L., Y. Pan, Z. Wang and C. Zhu. 2011. Heavy metal absorption status of five plant species in monoculture and intercropping. Plant Soil 345: 237-245.

Arnow L.E. 1937. Colorimetric determination of the components of 3,4-dihydroksyphenylalanine-tyrosine mixtures. J. Biol. Chem. 228: 531-537.

Atkin C.L., J.B. Neilands and H. Phaff. 1970. Rhodotorulic acid from species of Rhodospirillum, Rhodotorula, Sporidiobolus and Sporobolomyces. J. Bacteriol. 103: 722-733.

Atkinson N.J. and P.E. Urwin. 2012. The interaction of plant biotic and abiotic stresses: from genes to the field. J. Exp. Bot. 63(10): 3523-3544.

Atlas R.M. 1995. Handbook Media for Environmental Microbiology. CRC Press, Boca Raton.

Bradford M.M. 1976. A rapid and sensitive method for quantification of microgram quantities of proteins utilizing the principle of protein-dye binding. Anal. Biochem. 72: 248-254.

Brandt S. 1999. Date analysis. Statistical and computational methods for scientist and engineers, $3^{\text {th }}$ ed. Springer-Verlang, New York.

Chen G., Y. Liu, R. Wang, J. Zhang and G. Owens. 2013. Cadmium adsorption by willow root: the role of cell walls and their subfractions. Environ. Sci. Pollut. Res. 20: 5665-5672.

Chen L., S. Luo, X. Xiao, H. Guo, J. Chen, Y. Wan, B. Li, T. Xu, Q. Xi, C. Rao and others. 2010. Application of plant growth-promoting endophytes (PGPE) isolated from Solanum nigrum L. for phytoextraction of Cd-polluted soils. Appl. Soil Ecol. 46: 383-389. Cheraghi M., B. Lorestani, N. Khorasani, N. Yusefi and M. Karami. 2011. Finding on the phytoextraction and phytostabilization of soils contaminated with heavy metals. Biol. Trace Elem. Res. 144: 1133-1141.

Comas L.H., D.M. Eissenstat and A.N. Lakso. 2000. Assessing root death and root system dynamic in a study of grape canopy pruning. New Phytol. 47: 171-178.

Csaky T.Z. 1948. On the estimation of bound hydroxylamine in biological materials. Acta Chem. Scand. 2: 370-386. 
de Ascencao A.R.F.D.C. and I.A. Dubery. 2003. Soluble and wallbound phenolics and phenolic polymers in Musa acuminataroots exposed to elicitors from Fusarium oxysporum f.sp. cubense. Phytochemistry 63: 679-686.

dell'Amico E., L. Cavalca and V. Andreoni. 2005. Analysis of rhizobacterial communities in perennial Gramicaceae from polluted water meadow soil, and screening of metal-resistant, potentially plant growth-promoting bacteria. FEMS Microbiol. Ecol. 52: 153-162.

Elobeid M., C., Göbel, I. Feussner and A. Polle. 2012. Cadmium interferens with auxin physiology and lignification in poplar. J. Exp. Bot. 63(3): 1413-1421.

Fiedler H.D., J.L. Westrup, A.J. Souza, A.D. Pavei, C.U. Chagas and F. Nome. 2004. Cd (II) determination in the presence of aqueous micellar solutions. Talanta 64: 190-195.

Ganesan V. 2012. Rhizoremediation: a pragmatic approach for remediation of heavy metal-contaminated soil, pp. 147-162. In: Zaidi A., P.A. Wani and M.S. Khan (eds). Toxicity of heavy metals to legumes and bioremediation. Springer-Verlag Wien.

Gerhardt K.E., X.-D. Huang, B.R. Glick and B.M. Greenberg. 2009. Phytoremediation and rhizoremediation of organic soil contaminants: Potential and challenges. Plant Sci. 176: 20-30.

Grodzińska K. and G. Szarek-Łukaszewska. 2009. Heavy metal vegetation in the Olkusz region (Southern Poland) - preliminary studies. Pol. Bot. J. 54(1): 105-112.

Haoliang L., Y. Chongling and L. Jingchum. 2007. Low-molecular-weight organic acids exuded by mangrove (Kandelia candel (L.) Druce) roots and their effect on cadmium species change in the rhizosphere. Environ. Exp. Bot. 61: 159-166.

Huang P.M. and J.J. Germina. 2002. Chemical and biological processes in the rhizosphere: metal pollutants, pp.381-438. In: Huang P.M., J.-M. Bollag and N. Senesi (eds). Interaction between soil particle and microorganisms. Impact on the terrestrial ecosystem. IUPAC series on analytical and physical chemistry of environmental systems, vol. 8. John Wiley \& Sons LTD, Chichester.

Jha P.N., G. Gupta, P. Jha and R. Mehrotra. 2013. Association of rhizospheric/endophytic bacteria with plants: a potential gateway to sustainable agriculture. Greener J. Agric. Sci. 3(2): 73-84.

Kacálková L., P. Tlustoš and J. Száková. 2014. Chromium, nickel, cadmium, and lead accumulation in maize, sunflower, willow, and poplar. Pol. J. Environ. Stud. 23 (3): 753-761.

Kamaludeen S.P.B. and K. Ramasamy. 2008. Rhizoremediation of metals: harnessing microbial communities. Indian J. Microbiol. 48: 80-88.

Kao P.-H., C.-C. Huang and Z.-Y. Hseu. 2006. Response of microbial activities to heavy metals in a neutral loamy soil treated with biosolid. Chemosphere 64: 63-70.

Khan M.I.R., M. Fatma, T.S. Per, N.A. Anjum and N.A. Khan. 2015. Salicylic acid-induced abiotic stress tolerance and underlying mechanisms in plants. Front. Plant Sci. 6: 462-478.

Kim K.-R., G. Owens, R. Naidu and S.-I. Kwon. 2010. Influence of plant roots on rhizosphere soil solution composition of long-term contaminated soils. Geoderma 155: 86-92.

Kurek E. and M. Majewska. 2004. In vitro remobilization of Cd immobilized by fungal biomass. Geoderma 122: 235-246.

Kurek E. and M. Majewska. 2012. Microbially mediated transformations of heavy metals in rhizosphere, pp. 129-146. In: Zaidi A., P.A. Wani and M.S. Khan (eds). Toxicity of heavy metals to legumes and bioremediation, Springer-Verlag Wien.

Li Y., L. Wang, L. Yang and H. Li. 2014. Dynamics of rhizosphere properties and antioxidative responses in wheat (Triticum aestivum L.) under cadmium stress. Ecotox. Environ. Safe 102: 55-61.

Lou Y., H. Luo, T. Hu, H. Li and J. Fu. 2013. Toxic effects, uptake, and translocation of $\mathrm{Cd}$ and $\mathrm{Pb}$ in perennial ryegrass. Ecotoxicology 22: $207-214$
Madhaiyan M., S. Poonguzhali and S. Tongmin. 2007. Metal tolerating methylotrophic bacteria reduces nickel and cadmium toxicity and promotes plant growth of tomato (Lycopersicon esculentum L.). Chemosphere 69: 220-228.

Majewska M., E. Kurek and D. Szlachetka. 2006. Microbial activity - factor increasing retention of $\mathrm{Cd}$ added to soil. Pol. J. Environ. Stud. 15(2a): 127-134.

Majewska M. and E. Kurek. 2011. Effect of Cd concentration in growth media on Secale cereale roots and Cd interaction with rhizosphere microorganisms originating from different parts of the grain. Eur. J. Soil. Biol. 47: 95-101.

Majewska M., E. Kurek and A. Słomka. 2011. Effect of plant growth on total concentrations of $\mathrm{Zn}, \mathrm{Pb}$, and $\mathrm{Cd}$, and their distribution between operational fractions in the upper layer of a 100-year-old zinc-lead waste heap. Pol. J. Environ. Stud. 20(3): 591-297.

Martin J.P. 1950. Use of acid, rose bengal and streptomycin in the plate method for estimating soil fungi. Soil Sci. 38: 215-220.

Mendez M.O. and R.M. Maier. 2008. Phytostabilization of mine tailing in arid and semiarid environments - an emerging remediation technology. Environ. Health Persp. 116(3): 278-283.

Philippot L., J.M. Raaijmakers, P. Lemanceau and W.H. van der Putten. 2013. Going back to the roots: the microbial ecology of the rhizosphere. Nat. Rev. Microbiol. 11: 789-799.

Renella G., L. Landi and P. Nannipieri. 2004. Degradation of low molecular weight organic acids complexed with heavy metals in soil. Geoderma 122: 311-315.

Schützendübel A., P. Schwanz, T. Teichmann, K. Gross, R. Langenfeld-Heyser, D.L. Godbold and A. Polle. 2001. Cadmiuminduced changes in antioxidative systems, hydrogen peroxide content, and differentiation in scots pine roots. Plant Physiol. 127: 887-898.

Šćiban M.B., M.T. Klašnja and M.G. Antov. 2011. Study of the biosorption of different heavy metal ions onto Kraft lignin. Ecol. Eng. 37: 2092-2095.

Semenov V.M., A.S. Tulina, N.A. Semenova and L.A. Ivannikova 2013. Humification and nonhumification pathways of the organic matter stabilization in soil: A review. Eurasian Soil Sci. 46(4): 355-368.

Sipos G., Á. Solti, V. Czech, I. Vashegyi, B. Tóth, E. Cseh and F. Fodor. 2013. Heavy metals accumulation and tolerance of energy grass (Elymus elongates subsp. ponticus cv. Szavasi-1) grown in hydroponic culture. Plant Physiol. Bioch. 68: 96-103.

Soleimani M., H.A. Hajabbasi, M. Afyuni, A. Mirlohi, O.K. Borggaard and P.E. Holm. 2010. Effect of endophytic fungi on cadmium tolerance and bioaccumulation by Festuca arundinacea and Festuca pratensis. Int. J. Phytoremediat. 12: 535-549.

Van der Perk M. 2006. Soil and Water Contamination from Molecular to Catchment Scale. Taylor \& Francis/Balkema, Leiden.

Xu Y. and F.M.M. Morel. 2013. Cadmium in Marine Phytoplankton, pp. 509-528. In: Sigiel A., Sigiel, H. and R.K.O. Sigiel, (eds). Cadmium: From Toxicity to Essentiality, Metal Ions in Life Sciences. Springer Sciences + Business Media, Dordrecht.

Yin Y., Y. Wang, Y. Liu, G. Zeng, X. Hu, X. Hu, L. Zhou, Y. Guo and J. Li. 2015. Cadmium accumulation and apoplastic and symplastic transport in Boehmeria nivea (L.) Gaudich on cadmium-contaminated soil with the addition of EDTA or NTA. RSC Advances 5: 47584-47591.

Zhang S., T. Li, H. Huang, Z. Zou, X. Zhang, H. Yu, Z. Zheng and Y. Wang. 2012. Cd accumulation and phytostabilization potential of dominant plants surrounding mining tailings. Environ. Sci. Pollut. Res. 19: 3879-3888.

Zhang Y., S. Xu, S. Yang and Y. Chen. 2015. Salicylic acid alleviates cadmium-induced inhibition of growth and photosynthesis through upregulating antioxidant defense system in two melon cultivars (Cucumis melo L.). Protoplasma 252: 911-924. 